\title{
MYCORRHIZATION STIMULANT BASED IN FORMONONETIN ASSOCIATED TO FUNGICIDE AND DOSES OF PHOSPHORUS IN SOYBEAN IN THE CERRADO
}

\author{
ESTIMULANTE DE MICORRIZAÇÃO A BASE DE FORMONONETINA ASSOCIADO \\ À FUNGICIDA E DOSES DE FÓSFORO EM SOJA NO CERRADO
}

\section{Meire Aparecida Silvestrini CORDEIRO ${ }^{1}$; Dorotéia Alves FERREIRA ${ }^{2}$; Helder Barbosa PAULINO ${ }^{3}$; Claudio Roberto Fonseca SOUZA ${ }^{4}$;osé Oswaldo SIQUEIRA ${ }^{5}$; Marco Aurélio Carbone CARNEIRO ${ }^{6}$}

1. Professora Adjunta, Universidade Federal de Mato Grosso do Sul, Chapadão do Sul, MS, Brasil. meire.cordeiro@ufms.br; 2. Doutoranda do Programa de Pós-Graduação em Ciência do Solo da Escola Superior Luiz de Queiroz, Departamento de Ciência do Solo, Universidade de São Paulo, Piracicaba, SP, Brasil; 3. Professor Associado, Universidade Federal de Goiás, Regional de Jataí, Laboratório de Solos, Jataí, GO, Brasil; 4. Professor Adjunto, Departamento de Microbiologia, Imunologia e Parasitologia, Universidade Federal de Santa Catarina, Florianópolis, SC, Brasil;5. Professor Emérito, Departamento de Ciência do Solo, Universidade Federal de Lavras, Lavras, MG, Brasil e Instituto Tecnológico Vale, Belém, PA, Brasil. Bolsistas do CNPq; 6. Professor Associado, Departamento de Ciência do Solo, Universidade Federal de Lavras, Lavras, MG, Brasil. Bolsista do CNPq.

\begin{abstract}
Arbuscular mycorrhizal fungi (AMF) are obligatory biotrophics, which complicates the feasibility of producing inoculants. Thus, the discovery of substances capable of stimulating mycorrhizal colonization, like the isoflavone formononetin emerges as a promising alternative to explore the benefits of AMF native soil in extensive crops system. The aim of this study was evaluate the application of the isoflavone formononetin (7-hydroxy-4'-methoxy isoflavone) andfungicide via seed in Cerrado soil in no-tillage system and fertilization with two doses of phosphorus in soybean under field and controlled conditions. In the field experiment the treatments were three levels of formononetin $(0$, 0.5 and $1.0 \mathrm{mg}$ Formononetin seed ${ }^{-1}$ ) in the absence and presence of fungicide (Carbendazim + Thiram commercial mix) applied to seeds with two doses of phosphorus (100\% and 33\% of the recommended fertilization). The study was conducted until the maturation of soybeans. The greenhouse conditions experiment was implemented with the same treatments used in the field research and the flowering stage of the soybean plant was simulated water stress during 10 days, returning to normal irrigation until to harvest the soybean grain. Applying of formononetin stimulated the increased of mycorrhizal colonization, number of nodules, vegetative growth and soybean production in the greenhouse. In the field research the treatments contributed to attenuate the negative effect of the fungicide Carbendazim + Thiram in soybean reflecting increased soybean production and adequate supply of soil phosphorus besides high density of propagules of natives AMF that contributed to reduce the benefits of stimulating mycorrhizal (formononetin) in this research.
\end{abstract}

KEYWORDS: Isoflavone. Mycorrhizal fungi. Mycorrhizal colonization. Glycine max (L) Merril. Hydric stress.

\section{INTRODUCTION}

The arbuscular mycorrhizal fungi (AMFs) are obligatory biotrophics, belonging to the Glomeromycota phylum (SCHÜSSLER et al., 2001), which colonize the root of the majority of the vascular plants, forming mutualistic symbiosis, that provides many benefits and increased production of the colonized plants (MOREIRA; SIQUEIRA, 2006). These benefits are of great interest for legumes, mainly for soybean, especially when grown in tropical soils such as the Cerrado of Brazil, which have low availability and high fixation of $\mathrm{P}$ (YAMADA; ABDALLA, 2004). Mycorrhizal plants have greater development, favored nutrition, increased reclamation of fertilizer applied, also they are more tolerant to different types of biotic stresses (pests and diseases) and abiotic, such as water deficit (BETHLENFALVAY et al., 1990; FOLLI-
PEREIRA et al., 2012). This symbiosis between AMF and plant does not replace the phosphorus fertilization, however, it increases the efficiency of plant uptake of soil phosphorus in natural or added conditions, which makes it extremely important for Cerrado soils (CORDEIRO et al., 2005; FERREIRA et al., 2012).

The use of these fungi in annual crops like soybean, is limited due he availability and technical and economic viability of AMF inoculum production on a large scale, once these fungi are obligatory biotrophics (MOREIRA; SIQUEIRA, 2006). The discovery of substances able to stimulate mycorrhizal colonization, like the isoflavonoid formononetin (NAIR et al., 1991), appears as a promising alternative to exploit the benefits of native AMF in extensive crops system (SIQUEIRA et al., 2002).

Commercial products formulated based in 
formononetin have been used in some countries such as United States, Philippines, Japan, South Africa, Colombia and Canada, but not commercialized in Brazil (PHC, 2014). Several in vitro studies showed that formononetin is the main bioactive compound that works by stimulating the growth of assimbiotic AMF spores (BAPTISTA; SIQUEIRA, 1994; ROMERO; SIQUEIRA, 1996) and is also effective in increasing the growth of different plants in various regions the world, including Brazil (DAVIES-JUNIOR et al., 2005; NAIR et al., 1999; NOVAIS; SIQUEIRA, 2009; SIQUEIRA et al., 1992), but this type of work under field conditions and grain production in the Cerrado region in Brazil were not found..

In soybean crop are commonly employed treatments before to sowing, including the use of micronutrients, inoculation with nitrogen fixing bacteria and specific fungicides. The latter has become an essential practice to ensure the establishment of culture and high production due the increase of the phytosanitary problems (HENNING et al., 2010). Among the most commonly used fungicides for the control of soil borne pathogens in soybean seed treatment, stands out, the commercial mixture Carbendazim + Thiram (EMBRAPA, 2006). The Carbendazim, which is of the group of benzimidazoles, 2 - (methoxy-carbamoyl) benzimidazole-(Carbendazin) has systemic action on soil pathogens, and Thiram chemical group dimethyldithiocarbamate, tetramethylthiuram disulfide (Tiram) considered a contact fungicide. These products are considered toxic to AMF, which may compromise the establishment of symbiosis and its benefits for soybean crop (IPSILANTIS et al., 2012; O'CONNOR et al., 2002; SCHREINER; BETHLENFALVAY, 1997). Thus, the application of the mycorrhizal stimulant product based on synthetic formononetin, capable of accelerating the process of root colonization, associated to the seed treatment with fungicides process, can minimize the harmful effects of these pesticides to the plant, but needs to be evaluation with field experiments.

Therefore, the aim of this study was to evaluate the effects of the isoflavonoid formononetin (7-hydroxy-4'-methoxy-isoflavone) and fungicide applications in the seeds on mycorrhizal colonization and productivity in soybean crop in the Cerrado soil in tillage system with different doses of phosphorus in field and greenhouse system.

\section{MATERIAL AND METHODS}

This study consisted of two experiments, one conducted in field and the other in greenhouse conditions. The field research was conducted in October 2006 till February 2007 in experimental area of the Jatai Reginal of the Federal University of Goias, defined by the coordinates $17^{\circ} 53$ 'S and $51^{\circ}$ $43^{\prime} \mathrm{W}$. The climate of the region according to the Köpen classification is $\mathrm{Cw}$ type, mesothermal, this time , September to February, the rainfall was $1380,3 \mathrm{~mm}$ and with an average temperature of 24 ${ }^{\circ} \mathrm{C}$. The precipitation and temperature data were provided by the Meteorological Station of the Federal University of Goias/Regional Jatai.

The soil of the area was classified as Latosol Red with slightly wavy relief, whose chemical and textural characteristics were: $\mathrm{pH} \mathrm{H}_{2} \mathrm{O}-6.4$, organic matter - $33.1 \mathrm{~g} \mathrm{~kg}^{-1}, \mathrm{P}-12.9 \mathrm{mg} \mathrm{dm}{ }^{-3} ; \mathrm{K}-135 \mathrm{mg}$ $\mathrm{dm}^{-3}, \mathrm{Ca}-740 \mathrm{mg} \mathrm{dm}{ }^{-3}, \mathrm{Mg}-158 \mathrm{mg} \mathrm{dm}^{-3}, \mathrm{Al}-2.7$ $\mathrm{mg} \mathrm{dm}{ }^{-3}, \mathrm{H}+\mathrm{Al}-411 \mathrm{mg} \mathrm{dm}{ }^{-3}$; sand $-570 \mathrm{~g} \mathrm{~kg}^{-1}$, silt $-130 \mathrm{~g} \mathrm{~kg}^{-1}$ and clay $-300 \mathrm{~g} \mathrm{~kg}^{-1}$.

The experimental field has about 50 ha and during 10 years, the no tillage system has been used in a succession of soybeans crop and corn or sorghum as second crops. In the 2005/2006 harvest, soybean was sown in October 2005, applying $2 \mathrm{~kg}$ of nitrogen $\mathrm{ha}^{-1}$ (urea), $60 \mathrm{~kg} \mathrm{ha}{ }^{-1} \mathrm{P}_{2} \mathrm{O}_{5}$ (triple superphosphate) and $40 \mathrm{~kg} \mathrm{ha}^{-1} \mathrm{~K}_{2} \mathrm{O}$ (chloride potassium), held in February 2006 the sorghum sowing, harvested in July/2006. In September 2006 the experimental area was desiccated using 4 L ha-1 of glyphosate, and the remaining amount of straw was $7.7 \mathrm{Mg}$ ha-1 uniformly distributed over the whole area.

Before the implementation of the experiment, samples were collected to assess the density of spores and AMF species present in the area (GERDEMANN; NICHOLSON, 1963), found 193 spores per $50 \mathrm{~mL}\left(3,8\right.$ spores $\left.\mathrm{mL}^{-1} \pm 0,4\right)$ being the predominant species were Acaulospora scrobiculata, Gigaspora margarita and Glomus sp.

The experiment consisted of a factorial scheme $3 \times 2 \times 2$ given three doses of formononetin, presence and absence of fungicide via soybean seed and two $\mathrm{P}$ doses (100 \% and 33\% of the recommended dose). The experimental design was a randomized block design with five replicates. Each plot had eight rows of $10 \mathrm{~m}$ long with row spacing of $0.45 \mathrm{~m}$ (area of $36 \mathrm{~m}^{2}$ ), being the useful plot for evaluations constituted of four rows of $8 \mathrm{~m}$ in length (area of $14.4 \mathrm{~m}^{2}$ ), with seeding rate of 20 seeds $\mathrm{m}^{-1}$. The stimulating product of mycorrhization (7hydroxy-4'-methoxy-isoflavone, Mycoform ${ }^{\circledR}$ ) called formononetin was inoculated in the seeds at concentrations of 0 (no inoculation), $0.5 \mathrm{mg} \mathrm{seed}^{-1}$ and $1.0 \mathrm{mg}$ seed $^{-1}$ and being this last dose recommended by the company Plant Health Care 
(PHC), INC., Pittsburgh, USA, supplier of the product.

The fungicide used in the seed treatment was the commercial mixture Carbendazim + Thiram (Protreat/BASF) in recommended dose of $200 \mathrm{~mL}$ in $100 \mathrm{~kg}^{-1}$ of seeds, respectively. The concentration used was equivalent to $30+70 \mathrm{~g}$ Carbendazim + Thiram, respectively, to $100 \mathrm{~kg}$ of seed following the recommendation of this product to soybean crop.

The doses related to phosphate fertilizer were determined based on soil analysis (P-12.9 mg $\mathrm{dm}^{-3}$ and $300 \mathrm{~g} \mathrm{~kg}^{-1}$ clay) according the recommendations for the Cerrado region by Souza and Lobato (2002). Thus, the recommended dose (100\%) involved the maintenance fertilization, corresponding to $60 \mathrm{~kg} \mathrm{ha}^{-1} \mathrm{P}_{2} \mathrm{O}_{5}$ and with the intention to use the ability of AMF to absorb phosphorus from the soil, $33 \%$ of the recommended dose was used $\left(20 \mathrm{~kg} \mathrm{ha}^{-1} \mathrm{P}_{2} \mathrm{O}_{5}\right)$. The fertilizer was applied in the furrow at the time of planting, using as source simple superphosphate $\left(18 \% \mathrm{P}_{2} \mathrm{O}_{5}\right)$. The soybean variety used was the conventional A7001, of the company Nidera Seeds. Upon seeding, the fertilization with potassium using $69 \mathrm{~kg} \mathrm{ha}^{-1}$ of $\mathrm{KCl}$ was performed, equivalent to $40 \mathrm{~kg} \mathrm{ha}^{-1} \mathrm{~K}_{2} \mathrm{O}$, for all plots as recommended by EMBRAPA (2006).

The seeds were inoculated with nitrogen fixing bacteria using commercial inoculant containing Bradyrhizobium elkanii, SEMIA strains 587 and 5019 in aqueous liquid medium with a minimum $1.5 \times 10^{9}$ bacteria $\mathrm{mL}^{-1}$. In all the seeds were also applied the micronutrients cobalt, molybdenum and zinc in the concentrations of 0.005 $\mathrm{mL}, 0.005 \mathrm{~mL}$ and $0,15 \mathrm{~mL}$ per $\mathrm{kg}$ of seeds and lastly the treatment with insecticide (Fipronil) in dosage of $200 \mathrm{~mL}$ per $100 \mathrm{~kg}$ of seeds was performed.

During the experiment the weeds were sprayed with herbicides Chlorimuron ethyl ( $30 \mathrm{~g}$ ha $\left.{ }^{1}\right)$ and Lactofen $\left(300 \mathrm{~mL} \mathrm{ha}^{-1}\right)$, for the control of insects Cerotoma sp., Anticarcia gemmatalis and Nezara viridula the insecticides Methamidophos $\left(300 \mathrm{~g} \mathrm{ha}^{-1}\right)$ and Cypermethrin $\left(80 \mathrm{~mL} \mathrm{~h}^{-1}\right)$ were used and was also applied the fungicide Estrubilurina $\left(200 \mathrm{~mL} \mathrm{ha}^{-1}\right)$ to prevent against the fungus Phakopsora pachirizi.

The assessment of mycorrhizal colonization was performed by sampling 20 plants per plot, taken with the aid of a shovel to remove the roots, being determined the colonization rate at 15 days after germination (DAG), stage V3 with third node, second trifoliate leaves, at $45 \mathrm{DAG}, \mathrm{R} 2$ stage full bloom and 60 DAG stage R5.4 50-75\% of the well grained pods. Approximately $1 \mathrm{~g}$ of the fine roots were removed, washed, clarified and then was held the staining with trypan blue according to Phillips and Haymann (1970). To determine the percentage of mycorrhizal colonization of the roots, the method of gridded plate according to Giovannetti and Mosse (1980) and the stereoscope microscope observation $(40 \mathrm{x})$ were used.

The number of nodules was assessed at 45 DAG, coinciding with the R2 stage of soybean, being 20 plants per plot collected randomly with the aid of a shovel to remove the roots containing rhizosphere soil on a sieve, seeking the removal of nodules that were subsequently counted.

Of the plants sampled for evaluation of mycorrhization and nodulation (45 DAG) the third and fourth trifoliate leaves with stems were removed to assess the nutritional status of the plants. The samples were placed in paper bags and dried in an oven with forced air circulation at $70^{\circ} \mathrm{C}$. Upon reaching constant weight, samples were removed from the oven, ground into a Willey mill and then was held the nitropercloric digestion to determine $\mathrm{P}$ (colorimetric), $\mathrm{K}$ (flame photometry), $\mathrm{Ca}, \mathrm{Mg}, \mathrm{Cu}$, $\mathrm{Fe}, \mathrm{Mn}$ (atomic absorption spectrophotometry) following the methodology described by Malavolta et al. (1997). The concentrations of $\mathrm{N}$ were determined by the Kjeldahl method.

To assess the effects of the treatments on the development and production of soybeans, the following determinations were performed: plant height $(\mathrm{cm})$, number of pods per plant (pods plant $\left.{ }^{-1}\right)$, 100 grain mass $(\mathrm{g})$ and grain yield $\left(\mathrm{kg} \mathrm{m}^{-2}\right)$.

The research in the greenhouse consisted of the same treatments deployed in the field (factorial scheme $3 \times 2 \times 2$ ), and the experimental design was completely randomized (CRD) with five replicates, totaling 60 vessels. The soil was collected in the same area of the field experiment in the $0-20 \mathrm{~cm}$ layer, also sieved $(2 \mathrm{~mm})$ and placed in vases with a capacity of $7 \mathrm{~kg}$ of soil until planting time. Considering the field experiment was utilized the same fertilizer the amount calculated according to the soil for each vessel weight being applied at sowing time. In each vessel eight seeds were planted, performing the thinning, allowing the growth of four soybean plants per vessel. Irrigation was carried out by weighing every two days to maintain $60 \%$ of the total pore volume occupied by water.

At 60 DAG in full bloom, the plants were subjected to water stress by interrupting the supply of water, simulating a hydric stress like veranico, common in this region, keeping the humidity between $23-25 \%$ (weight basis) through two daily weighings for 10 days, and the permanent wilting 
point for this soil was obtained in $20 \%$ humidity (weight basis), details on Carducci et al. (2011). After this period, adequate supply of water was restored to harvest the test to 100 DAG. Plants were harvested from the vessels and determined the mycorrhizal colonization, grain yield vase $\mathrm{e}^{-1}$, height $(\mathrm{cm})$, number of pods plant ${ }^{-1}$ and weight of 50 grains $(\mathrm{g})$.

All data were subjected to analysis of variance and to test the SISVAR statistical software version 4.3 (FERREIRA, 2008), with the original data of mycorrhizal colonization were transformed using arcsine $(x / 100)^{0.5}$ and the data of spores amount, number of nodules and number of pods, processed by the equation $(\mathrm{x}+0.5)^{0.5}$.

\section{RESULTS AND DISCUSSION}

In greenhouse research there was a significant effect $(\mathrm{p} \leq 0.05)$ only with the application of formononetin. The formononetin increased mycorrhizal colonization by mycorrhizal fungi (AMF) natives contributed to increases of $4 \%$ in plant height, $14 \%$ in the number of pods per plant and $11 \%$ in grain yield (Table 1). This stimulating effect agrees with several studies, which showed that formononetin application acts to accelerate the germination of spores of AMF colonization and increase in soybean roots (BAPTISTA; SIQUEIRA, 1994; PAULA; SIQUEIRA, 1990; SILVAJUNIOR; SIQUEIRA, 1997), due to these benefits for the plant, the fomononetina is already released in several countries (PHC, 2014)

Table 1. Effect of formononetin on the percentage of mycorrhizal colonization, production and vegetative parameters studied in greenhouse research.

\begin{tabular}{lccccc}
\hline Formononetin & $\begin{array}{c}\text { Mycorrhizal } \\
\text { colonization }\end{array}$ & Height & $\begin{array}{c}\text { Mass of } 50 \\
\text { seeds }\end{array}$ & Pods & Production \\
\hline $\mathrm{mg} / \mathrm{seed}$ & $\%$ & $\mathrm{~cm}$ & $\mathrm{~g}$ & $\mathrm{~N}^{\circ}$ plant $^{-1}$ & $\mathrm{~g} \mathrm{vase-}^{-1}$ \\
0 & $39 \mathrm{~b}$ & $76,9 \mathrm{~b}$ & $7,21 \mathrm{~b}$ & $14 \mathrm{~b}$ & $12,82 \mathrm{~b}$ \\
0,5 & $47 \mathrm{a}$ & $79,9 \mathrm{a}$ & $7,34 \mathrm{~b}$ & $18 \mathrm{a}$ & $14,24 \mathrm{a}$ \\
1,0 & $54 \mathrm{a}$ & $81,7 \mathrm{a}$ & $8,08 \mathrm{a}$ & $16 \mathrm{ab}$ & $13,14 \mathrm{ab}$ \\
$\mathrm{CV} \%$ & 10 & 8 & 9 & 9 & 12 \\
\hline
\end{tabular}

Means followed by the same minuscule letter in the column do not differ by Tukey test at $5 \%$ of probability.

The availability of water in the soil is important at different stages of soybean development, specifically in the flowering/filling stage when the water deficit causes losses in grain yield (CONFALONE; DUJMOVICH, 1999). In this sense, processes that ensure greater soil exploration by roots and hyphae of AMF can contribute to reducing the adverse effects of lack of water for the crop. The results of this study indicate that the application of formononetin increase colonization and this decrease the effect of water stress. This is due to the advantage of water-plant relationship promoted by mycorrhizal which is the result of increases in transpiration rate and stomas opening, improved nutritional status and increase of root length and depth (MOREIRA; SIQUEIRA, 2006).

In the field researchthe application of formononetin promoted increased mycorrhizal colonization from 15 days after germination till grain filling (R5.4) and differed significantly ( $\mathrm{p} \leq$ 0.05 ) of the treatment without formononetin (Figure 1a). This demonstrates the effectiveness of formononetin in cropping systems, ensuring the stimulating effect of native AMF providing more than $20 \%$ increase in mycorrhizal colonization, regardless of the other factors studied, several studies in greenhouse related the same with this plant (BAPTISTA; SIQUEIRA, 1994; PAULA; SIQUEIRA, 1990; SILVA-JUNIOR; SIQUEIRA, 1997).

The number of nodules varied only due to the application of formononetin, with no effect of other treatments or the interaction of the factors studied. It was observed, as seen in mycorrhizal colonization, plants that received formononetin had higher number of nodules in relation the plants that not were application of with this product, evidencing the favoring of nodulation when it is used (Figure 1b). The isoflavonoid formononetin does not induce the activation of nodulation genes (HUNGRIA, 1994), but may act indirectly on nodulation once it promotes an increase in mycorrhizal colonization, increasing the absorption of phosphorus, supplying the high demand of this nutrient for the nodules. 

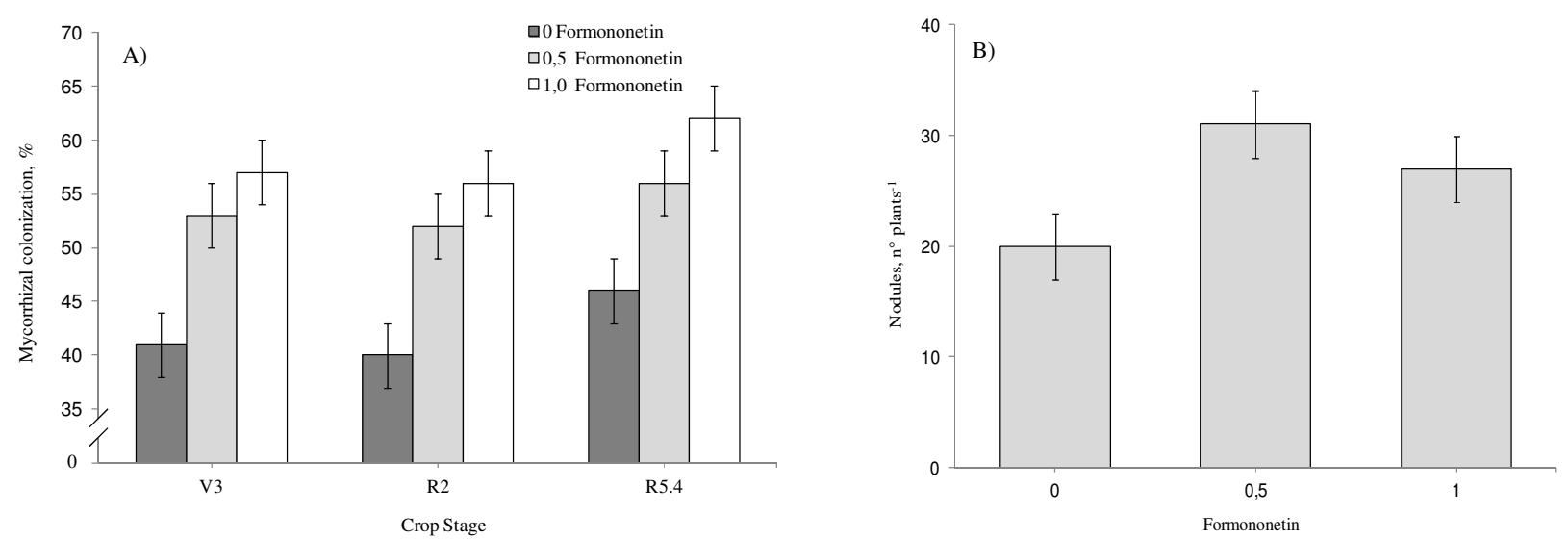

Figure 1. Mycorrhizal colonization (A) at different stages of soybean and number of nodules (B) at flowering, in consolidated no tillage system, depending on the application of formononetin the field. Coincident bars do not differ by Tukey test at $5 \%$ of probability.

These results corroborate with several studies under controlled conditions with soybean and isoflavonoid formononetin (FRIES et al., 1998; SILVA-JUNIOR; SIQUEIRA, 1997) which increases in mycorrhizal colonization stimulated by this isoflavonoid were verified. The highest mycorrhizal colonization and the shorter time promoted by the use of formononetin represent a potential for soybean crop to overcome adverse conditions such as the dry spells and increase the efficiency in the use of fertilizers, especially phosphorus, commonly occurring factors in the Cerrado.

The soybean production was influenced by fungicide and its interaction with formononetin $(\mathrm{p} \leq$ $0.10)$ no effect of others treatments and their interactions were checked. Fungicide application reduced the production of soybeans in $12 \%$, a fact confirmed by Zilli et al. (2009). However, when there was the use of stimulant to mycorrhization, $0.5 \mathrm{mg} \mathrm{seed}^{-1}$ this effect was alleviated, contributing to a gain equivalent to $300 \mathrm{~kg}$ of soybeans per hectare in comparison with the control without formononetin and with fungicides (Table 2), thus showing a bioprotection effect promoted by the use of formononetin. As the use of these fungicides in seed treatment is a very important practice for the proper establishment of soybean crop (HENNING et al., 2010), the application of formononetin can contribute to minimizing the damaging effects of fungicides for the mycorrhizal colonization thus ensuring the high soybean production in the Cerrado.

Table 2. Production of soybeans crop due to the application of fungicide and formononetin, in no tillage system of Cerrado.

\begin{tabular}{|c|c|c|}
\hline \multirow{2}{*}{$\begin{array}{l}\text { Formononetin } \\
\text { (mg/seed) }\end{array}$} & \multicolumn{2}{|c|}{ Fungicide } \\
\hline & Absence & Presence \\
\hline 0 & $0,33(55) \mathrm{Aa}$ & $0,29(48) \mathrm{Bb}$ \\
\hline 0,5 & $0,33(55) \mathrm{Aa}$ & $0,32(53) \mathrm{Aa}$ \\
\hline 1,0 & $0,31(52) \mathrm{Aa}$ & $0,29(48) \mathrm{Ab}$ \\
\hline
\end{tabular}

Means followed by the same capital letter on the line and minuscula letters in the column do not differ by Tukey test at $10 \%$ of probability. Values in brackets refer to estimates sacks $(60 \mathrm{~kg})$ per hectare.

Another result observed was the not inhibition of mycorrhizal colonization due to applying fungicide Carbendazim + Thiram even Carbendazim belongs to the chemical group of benzimidazoles, considered inhibitor of AMF (SCHREINER; BETHLENFALVAY, 1997; IPSILANTIS et al., 2012; O'CONNOR et al., 2002;). However, the use of formononetin, dose 0.5, served to increasing the mycorrhizal colonization, increasing the number of nodules (Fig. 1a and b) and consequently the protection of the plant to the deleterious effects caused by fungicides, (Table 2). This is due to changes introduced by formononetin in natives AMF that accelerate the mycorrhizal colonization and enhance the positive effects of these fungi and changes in plant physiology and the 
negative effects of pesticides. Similar effect was reported by Siqueira et al. (1991a) for formononetin in protecting plants against the residual effect of herbicides, confirming the results found in this study.

The foliar nutrients concentrations were not affected by experimental treatments and their interactions and all the macro and micronutrients were found in the proper range for soybean (OLIVEIRA, 2004). The concentration of phosphorus in all treatments were appropriate, however, we can observe a trend $(\mathrm{p} \leq 0.20)$ up to 12 $\%$ increase in levels of this nutrient in plants with formononetin (4.72 $\mathrm{g} \mathrm{kg}^{-1}$ ) compared with the control treatment $\left(4.2 \mathrm{~g} \mathrm{~kg}^{-1}\right)$. This increased the absorption of $\mathrm{P}$, even without significant effect, may have contributed to the increase in grain production, indicating benefits of formononetin even in conditions of adequate $\mathrm{P}$ supply, as revealed by analyzes of the foliar concentrations of this nutrient.

Thus, with the application of $33 \%$ of the recommended dose of $\mathrm{P}$, there was no increase in foliar levels of this nutrient in the plant, indicating that fertilization based on soil chemical analysis, was sufficient to ensure adequate phosphate nutrition for soybean. Successive fertilization of the area assured residual effect of this nutrient in consolidated no tillage system (MARTINAZZO et al., 2007), situation that may explain the reduced effect of formononetin in phosphorus uptake by plants observed in this study.

The application of formononetin promoted a $52 \%$ increase in the production of soybeans crop in field experiments in Lavras (MG) found by Siqueira et al. (1992). It is noteworthy that the soil conditions, especially the availability of $\mathrm{P}$ in the soil, the time of adoption of no-tillage system and climatic conditions were different from the present study. Another aspect that may have contributed to the smaller positive effect of formononetin was the spore density of native AMF in the soil, being recovered 193 AMF spores $50 \mathrm{~mL}$ in soybean flowering, considered high for the stimulating action of formononetin as reported by Siqueira et al. (1991b). Furthermore, the water regime in the period of this study was satisfying and well distributed with $1380 \mathrm{~mm}$ of rainfall during the crop cycle as well as the temperature was favorable to the soybean crop (average $24.3{ }^{\circ} \mathrm{C}$ ) and there was no type of environmental stress for culture, unlike what occurred in the greenhouse research, where there was high water stress and response to application of formononetin.

The world reserves of phosphate for fertilizer production are running out and this is one of the major macronutrients responsible for the growth of plants (LOPES et al., 2004). Most of the phosphorus applied via fertilizer becomes unavailable, retained in the soil colloids mainly bonded with $\mathrm{Fe}$ and $\mathrm{Al}$ (PINTO et al., 2013). In this sense strategies to increase the efficiency of utilization of this phosphorus should be a priority for the development of agriculture. The results of this study demonstrate the beneficial effects of application of formononetin for soybean promoting greater mycorrhizal colonization and faster, higher $\mathrm{P}$ uptake trend, relieving the stress caused by the fungicide and water favoring the increase of production of soybean.

\section{CONCLUSIONS}

The application of formononetin stimulated the mycorrhizal colonization, number of nodules, vegetative growth and production of soybean grains under conditions of simulated water deficit

Formononetin applied via seed $0.5 \mathrm{mg} \mathrm{seed}^{-1}$ caused increased mycorrhizal colonization, nodules number and grain production of soybean crop and reduced the negative effects of fungicides Carbendazim + Thiram in soybean production in the field experiment.

\section{ACKNOWLEDGMENTS}

The Federal University of Goiás/Regional Jatai - Jataí (GO) by the release of the experimental area and logistical support, to $\mathrm{CNPq}$ for financial support (process 577559/2008-7) and a research grant (process 308207/2011-4). To Capes for the master's degree grant given to the first author.

RESUMO: Os fungos micorrízicos arbusculares (FMAs) são biotróficos obrigatórios, o que dificulta a viabilidade da produção de inoculantes. Com a descoberta de substâncias capazes de estimular a colonização micorrízica, o isoflavonóide formononetina surge como uma alternativa promissora para explorar os benefícios dos FMAs nativos do solo em cultivos extensivos. O objetivo do presente estudo foi de avaliar os efeitos das aplicações do isoflavonóide formononetina (7-hydroxy-4'-methoxy isoflavone) e de fungicida nas sementes em solo do Cerrado no sistema de plantio direto com duas doses de fósforo na cultura da soja em campo e em casa de vegetação. No experimento de campo os tratamentos foram três doses de formononetina $\left(0,0,5\right.$ e $1,0 \mathrm{mg}$ de Formononetina semente $\left.{ }^{-1}\right)$; na ausência e presença de 
fungicida (Mistura comercial Carbendazim + Thiram) aplicado via semente e duas doses de fósforo (100\% e $33 \%$ da adubação recomendada). O experimento de casa de vegetação foi implantado com os mesmos tratamentos utilizado no estudo em campo e na fase de florescimento das plantas de soja foi simulado um estresse hídrico, por 10 dias, retornando a irrigação normal até a colheita dos grãos. A aplicação de formononetina estimulou aumento da colonização micorrízica, número de nódulos, crescimento vegetativo e a produção de grãos soja em condições de déficit hídrico simulado em casa de vegetação e no no estudo de campo contribui para amenizar o efeito negativo dos fungicidas nas plantas de soja refletindo em aumento da produção da soja.

PALAVRAS-CHAVE: Isoflavonóides. Fungo micorrízico. Colonização micorrízica. Estresse hídrico. Glycine $\max (\mathrm{L})$ Merril.

\section{REFERENCES}

BAPTISTA, M. J.; SIQUEIRA, J. O. Efeito de flavonóides na germinação de esporos e no crescimento assimbiótico do fungo micorrízico arbuscular Gigaspora gigantea. Revista Brasileira de Fisiologia Vegetal, Campinas, v. 6, n. 2, p. 127-134, 1994.

BETHLENFALVAY, G. J.; BROWN, M. S.; FRANSON, R. L. Glycine-glomus-bradyrhizobium symbiosis: X. Relationships between leaf gas exchange and plant and soil water status in nodulated, mycorrhizal soybean under drought stress. Plant Physiology, Washington, v. 94, n. 2, p. 723-728, 1990.

http://dx.doi.org/10.1104/pp.94.2.723

CARDUCCI, C. E.; OLIVEIRA, G. C.; SEVERIANO, E. C.; ZEVIANI, W. M. Modelagem da curva de retenção de água de Latossolos utilizando a equação dupla van Genuchten. Revista Brasileira de Ciência do Solo, Viçosa, v. 35, n. 1, p. 77-86, 2011.

CONFALONE, A.; DUJMOVICH, M. N. Influência do déficit hídrico sobre o desenvolvimento e rendimento da soja. Revista Brasileira de Agrociência, Pelotas, v. 7, n. 2, p. 183-187, 1999.

CORDEIRO, M. A. S.; CARNEIRO, M. A. C.; PAULINO, H. B.; SAGGIN JÚNIOR, O. J. Colonização e densidade de esporos de fungos micorrízicos em dois solos do cerrado sob diferentes sistemas de manejo. Pesquisa Agropecuária Tropical, Goiânia, v. 35, n. 3, p. 147-153, 2005.

DAVIES-JÚNIOR, F. T.; CALDERÓN, C. M.; HUAMAN, Z.; GÓMEZ, R. Influence of a flavonoid (formononetin) on mycorrhizal activity and potato crop productivity in the highlands of Peru. Scientia Horticulturae, Amsterdam, v. 103, n. 3, p. 318-329, 2005. http://dx.doi.org/10.1016/j.scienta.2005.04.013

EMBRAPA- EMPRESA BRASILEIRA DE PESQUISA AGROPECUÁRIA-. Tecnologia de produção de soja: Região Central do Brasil 2005. (Sistemas de Produção, 9). Londrina: Embrapa Soja, 2006. 220p.

FERREIRA, D. F. SISVAR: um programa para análises e ensino de estatística. Revista Symposium, v. 6, n. 1, p. 36-41, 2008.

FERREIRA, D. A.; CARNEIRO, M. A. C.; SAGGIN-JUNIOR, O. J. Fungos micorrízicos arbusculares em um Latossolo Vermelho sob manejos e usos no cerrado. Revista Brasileira de Ciência do Solo, Viçosa, v. 36, n. 1, p. 51-61, 2012.

FOLLI-PEREIRA, M. S.; MEIRA-HADDAD, L. S.; BAZZOLLI, D. M. S.; KASUYA, M. C. M. Micorriza arbuscular e a tolerância das plantas ao estresse. Revista Brasileira de Ciência do Solo, Viçosa, v. 36, n. 6, p. $1663-1679,2012$.

FRIES, L. L. M.; PACOVSKY, R. S.; SAFIR, G. R. Influence of phosphorus and formononetin on isozyme expression in the Zea mays- Glomus intraradices symbiosis. Physiologia Plantarum, Copenhagen, v. 103, n. 2, p. 172-180, 1998. http://dx.doi.org/10.1034/j.1399-3054.1998.1030204.x 
GERDEMANN, J. W.; NICHOLSON, T. H. Spores of mycorrhizal Endogone species extracted from soil by wet sieving and decanting. Transactions of the British Mycological Society, Cambridge, v. 46, p. 235-244, 1963. http://dx.doi.org/10.1016/S0007-1536(63)80079-0

GIOVANNETTI, M.; MOSSE, B. An evaluation of techniques for measuring vesicular arbuscular mycorrhizal infection in roots. New Phytologist, Cambridge, v. 84, n. 3, p. 489-500, 1980. http://dx.doi.org/10.1111/j.14698137.1980.tb04556.x

HENNING, A. A.; FRANÇA-NETO, J. B.; KRZYZANOWSKI, F. C.; LORINI, I. Importância do tratamento de sementes de soja com fungicidas na safra 2010/2011, ano de "La Niña" (Circular Técnica 82). Londrina: Embrapa Soja, 2010. 8p.

HUNGRIA, M. Sinais moleculares envolvidos na nodulação de leguminosas por rizóbio. Revista Brasileira de Ciência do Solo, Viçosa, v. 8, n. 3, p. 339-364, 1994.

IPSILANTIS, I.; SAMOURELIS, C.; KARPOUZAS, D. G. The impact of biological pesticides on arbuscular mycorrhizal fungi. Soil Biology \& Biochemistry, Elmsford, v. 45, p. 147-155, 2012.

http://dx.doi.org/10.1016/j.soilbio.2011.08.007

LOPES, A. S.; SILVA, C. A. P.; BASTOS, A. R. R. Reservas de fosfatos e produção de fertilizantes fosfatados no Brasil e no mundo. In: YAMADA, T.; ABDALLA, S. R. S. (Ed). SIMPÓSIO SOBRE FÓSFORO NA AGRICULTURA BRASILEIRA, 1., 2004, Piracicaba. Anais...Piracicaba: POTAFOS, 2004. p. 13-34.

MALAVOLTA, E.; VITTI, G. C., OLIVEIRA, S. A. Avaliação do estado nutricional das plantas: princípios e aplicações. Piracicaba: Potafos, 1997. 319p.

MARTINAZZO, R.; RHEINHEIMER, D. S.; GATIBONI, L. C.; BRUNETTO, G.; KAMINSKI, J. Fósforo microbiano do solo sob sistema plantio direto em resposta a adição de fosfato solúvel. Revista Brasileira de Ciência do Solo, Viçosa, v. 31, n. 3, p. 563-570, 2007.

MOREIRA, F. M. S.; SIQUEIRA, J. O. Microbiologia e Bioquímica do solo. Lavras: UFLA, 2006. 729p.

NAIR, M. G.; SAFIR, G. N.; SIQUEIRA, J. O. Isolation and identification of vesicular arbuscular mycorrhiza stimulatory compounds from clover (Trifolium repens) roots. Applied and Environmental Microbiology, Washington, v. 5, n. 2, p. 434-439, 1991.

NAIR, M. G.; BALASUBRAMANIAN, S.; KELLY, J. F.; SCHUTZKI, R. E.; WENZL, P.; CHÁVEZ A. L. Natural products as potential soil amendments for crop improvement. In: SIQUEIRA, J. O.; MOREIRA, F. M. S.; LOPES, A. S.; GUILHERME, L. R. G.; FAQUIN,V.; FURTINI NETO, A. E.; CARVALHO, J. G. (Ed.). Inter-relação fertilidade, biologia do solo e nutrição de plantas. Viçosa, MG: SBCS/Lavras: UFLA/DCS, 1999. p. 405-419.

NOVAIS, C. B.; SIQUEIRA, J. O. Aplicação de formononetina na colonização e esporulação de fungos micorrízicos em braquiária. Pesquisa Agropecuária Brasileira, Brasília, v. 44, n. 5, p. 496-502, 2009. http://dx.doi.org/10.1590/S0100-204X2009000500009

O’CONNOR, P. J.; SMITH, S. E.; SMITH, F. A. Arbuscular mycorrhiza influence plant diversity and community structure in a semiarid herbland. New Phytologist, Cambridge, v. 154, n. 1, p. 209-218, 2002. http://dx.doi.org/10.1046/j.1469-8137.2002.00364.x

OLIVEIRA, S. A. Análise foliar. In: SOUSA, D. M.; LOBATO, E. (Ed.). Cerrado: correção do solo e adubação. Brasília: Embrapa Cerrados, 2004. p. 245-256. 
PAULA, M. A.; SIQUEIRA, J. O. Stimulation of hyphal growth of the VA mycorrhizal fungus Gigaspora margarita by suspension cultured Pueraria phaseoloides cells and cell products. New Phytologist, Cambridge, v. 115, n. 1, p. 69-73. 1990. http://dx.doi.org/10.1111/j.1469-8137.1990.tb00923.x

PHC- PLANT HEALTH CARE-. Disponível em: <http://www.planthealthcare.com>. Acesso em 01 de dezembro. 2014

PHILLIPS, J. M.; HAYMAN, D. S. Improved procedures for clearing roots and staining parasitic and vesicular-arbuscular mycorrhizal fungi for rapid assessment of infection. Transactions of the British Mycological Society, Cambridge, v. 55, n. 1, p. 158-161, 1970. http://dx.doi.org/10.1016/S00071536(70)80110-3

PINTO, F. A.; SOUZA, E. D.; PAULINO, H. B.; CURI, N.; CARNEIRO, M. A. C. P-sorption and desorption in savanna brazilian soils as a support for phosphorus fertilizer management. Ciência e Agrotecnologia, Lavras, v. 37, n. 6, p. 521-530, 2013.

ROMERO, A. G. F.; SIQUEIRA J. O. Atividade de flavonóides sobre esporos do fungo micorrízico Gigaspora gigantea in vitro. Pesquisa Agropecuária Brasileira, Brasília, v. 37, n. 7, p. 517-522, 1996.

SCHREINER, R. P.; BETHLENFALVAY, G. J. Plant and soil response to single and mixed species of arbuscular mycorrhizal fungi under fungicide stress. Applied Soil Ecology, Amsterdam, v. 7, n. 1, p. 93-102, 1997. http://dx.doi.org/10.1016/S0929-1393(96)00141-2

SCHÜSSLER, A.; SCHWARZOTT, D.; WALKER, C. A new fungal phylum, the Glomeromycota: phylogeny and evolution. Mycological Research, Cambridge, v. 105, n. 12, p. 1413-1421, 2001.

http://dx.doi.org/10.1017/S0953756201005196

SILVA-JÚNIOR, J. P.; SIQUEIRA, J. O. Aplicação de formononetina sintética ao solo como estimulante da formação de micorriza no milho e na soja. Revista Brasileira de Fisiologia Vegetal, Campinas, v. 9, n. 1, p. 35-41, 1997.

SIQUEIRA, J. O.; BROWN, D. G.; SAFIR, G. R.; NAIR, M. G. Field application of the VA-mycorrhiza stimulating isoflavonoid formononetin (Rhizotropin ${ }^{\mathrm{TM}}$ ) on corn and soybean in Brazil. In: THE INTERNATIONAL SYMPOSIUM ON MANAGEMENT OF MYCORHIZAS IN AGRICULTURE, HORTICULTURE AND FORESTRY, 1992, Perth. Proceedings... Perth: University of Western Australia, 1992. 132p.

SIQUEIRA, J. O.; LAMBAIS, M. R.; STÜRMER, S. L. Fungos micorrízicos arbusculares. Biotecnologia, Ciência \& Desenvolvimento, Brasília, v. 25, p. 12-21, 2002.

SIQUEIRA, J. O.; SAFIR, G. R.; NAIR, M. G. VA-mycorrhizae stimulating and mycorrhiza isoflavonoid compounds reduce plant herbicide injury. Plant and Soil, The Hague, v. 134, n. 2, p. 233-242, 1991a. http://dx.doi.org/10.1007/BF00012041

SIQUEIRA, J. O.; SAFIR, G. R.; NAIR, M. G. Stimulation of vesicular-arbuscular mycorrhiza formation and growth of white clover by flavonoid compounds. New Phytologist, Cambridge, v. 118, n.1, p. 87-93, 1991b. http://dx.doi.org/10.1111/j.1469-8137.1991.tb00568.x

SOUZA, D. M. G.; LOBATO, E. Cerrado correção do solo e adubação. Planaltina, DF: Embrapa Cerrados, 2002. 416p.

YAMADA, T.; ABDALLA, S. R. S. Fósforo na Agricultura Brasileira. Piracicaba: POTAFOS, 2004, 726 p.

ZILLI, J. E.; RIBEIRO, K. G.; CAMPO, R. J.; HUNGRIA, M. Influence of fungicide seed treatment on soybean nodulation and grain yield. Revista Brasileira de Ciência do Solo, Viçosa, v. 33, n. 4, p. 917-923, 2009. 